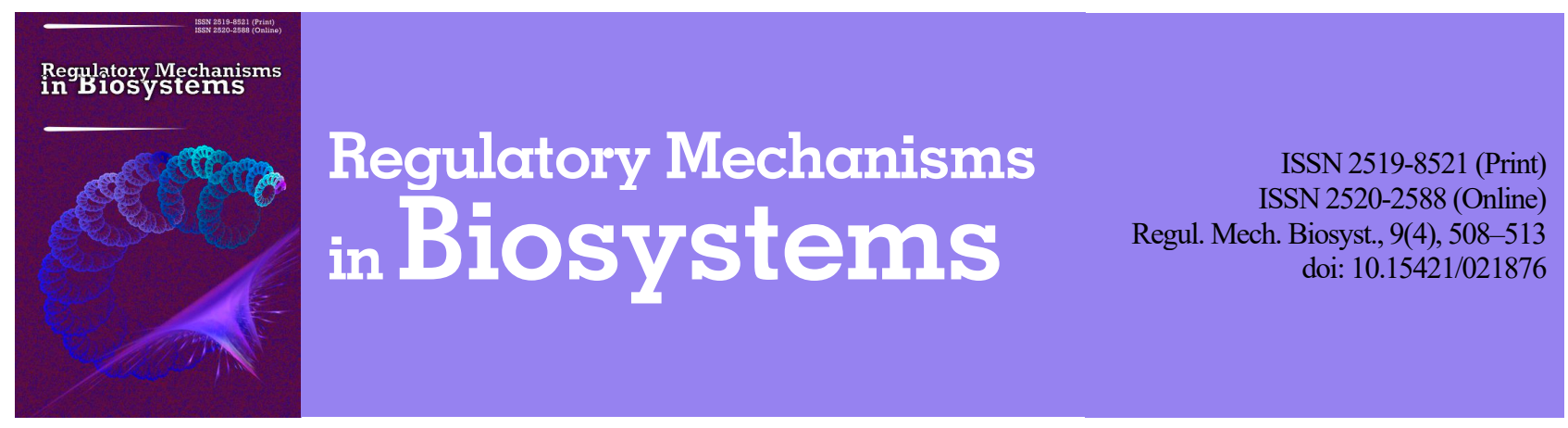

\title{
Hepato- and hemato-protective properties of $\alpha$-ketoglutarate under the combined effect of water-immobilization and emotional stress
}

\author{
O. O. Dyomshina, M. I. Koloda, G. O. Ushakova \\ Oles Honchar Dnipro National University, Dnipro, Ukraine
}

Article info

Received 28.10.2018

Received in revised form

20.11.2018

Accepted 27.11.2018

Oles Honchar Dnipro National University,

Gagarin av., 72,

Dnipro, 49010, Ukraine.

Tel.: +38-050-607-52-83.

E-mail:olga-d2009@ukr.net

\begin{abstract}
Dyomshina, O. O., Koloda, M. I., \& Ushakova, G. O. (2018). Hepato- and hemato-protective properties of a-ketoglutarate under the combined effect of water-immobilization and emotional stress. Regulatory Mechanisms in Biosystems, 9(4), 508-513. doi:10.15421/021876
\end{abstract}

This article presents the results of the combined effect of water-immobilization and emotional stress on haematological and morphological parameters of blood and liver status of rats in conditions of correction of the disorders using by $\alpha$-ketoglutarate. Experimental combined stress was induced by the interchangeable effect of dry immobilization and immersion in water for 3 days under constant illumination using an artificial lighting lamp of 1,000 lux., thus achieving a combined effect of stress. Physiological adaptation and administration of $0.8 \mathrm{~g} / \mathrm{kg}$ of body weight of $\alpha$-ketoglutarate lasted 14 days after stress induction. Haematological parameters were determined using the Automated Veterinary Hematology Analyzer PCE 90 Vet (High Technology Inc., USA), while biochemical parameters of the liver state were determined by spectrophotometric and colourimetric methods. The obtained results showed an increase in hemolysis, which was determined by a decrease in the number of erythrocytes and haemoglobin concentration in the blood of rats under the effect of the stress factors studied. A negative consequence of strengthening of hemolysis is the development of hypoxia in the liver, which causes the slowing of metabolic processes in its cells. As a result, there is an accumulation of partially oxidized products: lactate and pyruvate, increased formation of TBA-active products, and oxidative modification of proteins. During the 14 days of physiological adaptation after stress, the main indicators of blood and liver status of the rats were partially restored. A stronger recovery of redox status and improvement of the physiological state of the liver and, hence, haematological parameters, were noted for rats that received $\alpha$-ketoglutarate for 14 days after stress. The revealed general positive trend indicates the stimulation of adaptation processes and the overall functioning of the antioxidant system of the liver of rats in the use of $\alpha$-ketoglutarate against the background of the combined effects of water-immobilization and emotional stress.

Keywords: aminotranspherases; catalase; superoxidedismutase; TBA-active products, liver, blood

\section{Introduction}

The modern rhythm of life and the influence of physical and chemical stress factors form a constant stress background. The most sensitive tissues and organs of mammals under such conditions are the nervous system and blood, as well as the heart and the liver (Khnychenko \& Sapronov, 2003; Volkova \& Meleshkina, 2008; Sawa et al., 2017). Computerization of workplaces, which has led to the inactive condition of employees during the working day and an increase in the time spent by both children and adults sitting at the computer is a stressful load that worsens health (Warille et al., 2017). The chronic stage of stress conditions leads to a decrease in blood circulation due to vasoconstriction and an increase in the risk of developing hypoxic conditions in many organs and the nervous system (Ushakova et al., 2010; Tkachenko et al., 2018). Under such conditions, a large number of anaerobic metabolites find their way into the bloodstream, which leads to the development of oxidative stress (Lushchak, 2015; Sahafi, 2018, Wu, 2018). The liver ensures the processing of toxic metabolites, which in large quantities are formed in the body under stress conditions (Mikhaylenko et al., 2016; Serova et al., 2016; Dyomshina et al., 2017). As a result of stress factors in the liver, the processes of glycogenolysis and glycollysis are activated, prooxidant and antioxidant homeostases are violated, and the disintegration of processes generating the formation and elimination of bilirubin increases the permeability of the liver cell membranes (Glinic, 2007; Sookoian, 2015; Mehra, 2016). Long-term metabolic changes in the body can lead to significant damages to the liver tissue, accumulation of secondary toxic metabolites, and decrease in the intensity of their excretion from the body (Svan, 2015; Baulies, 2018). Such aggressive metabolites include peroxide, TBA-active products (Shmarakov et al., 2014; Usende et al., 2018; Wu et al., 2018), oxidized modified proteins (Semchyshyn \& Lushchak, 2012; Lushchak, 2015; Pasko, 2016), and partially oxidized intermediate metabolites like pyruvate and lactate (Sterling et al., 2015; Vincent et al., 2016).

The search for natural compounds that prevent the development of oxidative stress is of interest to many scholars. Naturally occurring ketoacids are now actively considered among the known substances that can restore metabolic processes in damaged cells (Krebs \& Johnson, 1980; Andrae et al., 1985; Dakshayani et al., 2006; Zdzisińska et al., 2017). One of the representatives of the ketoacids is $\alpha$-ketoglutarate, an intermediate metabolite of the tricarboxylic acid cycle, a supplier of the cell's energy (Ushakova et al., 2010; Kovalenko et al., 2011; Tkachenko et al., 2018). Due to the lack of $\alpha$-ketoglutarate in mammals, the rate of oxidation of carbohydrates, proteins, and lipids are reduced; blocked reactions of transamination and of reduction of free ammonia with the participation of glutamate dehydrogenase, which is of paramount importance, especially in the brain (Velvizhi et al., 2002; Yao, 2012; Banerjee et al., 2016). This ketoacid has antioxidant properties (Andrae et al., 1985; Harrison, 2008), participates in non-enzymatic decarboxylation during the decomposition of hydroperoxide (Sokołowska et al., 1999; Long \& Halliwell, 2011), and detects functions of reducing oxidized low molecular weight antioxidants and antioxidant enzymes (Dakshayani et al., 2006). The purpose of this study is to determine the degree of liver damage under the 
combined effects of water-immobilization and emotional stress and after the correction of this state with $\alpha$-ketoglutarate.

\section{Materials and methods}

The experiment was conducted on white mature Wistar male rats weighing 180-230 g that were kept under standard vivarium conditions. Animal manipulation was carried out in accordance with the rules of the "European Convention for the Protection of Vertebrate Animals Used for Experimental and Other Scientific Purposes" (Strasbourg, 1986). The method was analyzed and approved by the local ethics committee of the Oles Honchar Dnipro National University. Animals for the experiment were grouped according to the purpose:

1 - intact animals without experimental pathology that received the usual diet, with free access to food and drinking water;

2 - animals with experimental pathology (3 days);

3 - animals with a 14-day period of physiological adaptation after experimental pathology;

4 - animals that received $0.8 \mathrm{~g} / \mathrm{kg}$ body weight of oral $\alpha$-ketoglutarate for 14 days after experimental pathology.

In the experiment, a modified, well-known model of water-immobilization stress was used (Weiner, 1996). Experimental pathology was induced by the interchangeable effect of dry immobilization and immersion in water for three days under constant lighting during the experimental model using an artificial lighting lamp 1000 lux, which resulted in a combined stress effect.

After completing the reproduction of the experimental model, the animals were weighed and withdrawn from anaesthesia (thiopental $60 \mu \mathrm{g} / \mathrm{kg}$ ). Blood was drawn with the addition of an anticoagulant of sodium citrate for further analysis. The determination of the quantitative parameters of haematological and morphological factors in the blood was carried out on an automatic analyzer, Automated Veterinary Hematology Analyzer PCE 90 Vet (High Technology Inc., USA) at the Research Center for Biosafety and Environmental Control of Agroindustrial Resources, Dnipro State Agro-Economic University. The liver was removed, washed twice with a physiological solution, weighed, its volume and size were measured, it was purified from haemoglobin residues, and was homogenized in a buffer solution: $250 \mathrm{mM}$ sucrose, $1 \mathrm{mM}$ ethylenediaminetetraacetate (EDTA), $10 \mathrm{mM}$ Tris- $\mathrm{HCl}, 2 \mathrm{mM} \mathrm{MgCl}_{2}, \mathrm{pH} 7.4$ at $0-3{ }^{\circ} \mathrm{C}$ (Wieckowski et al., 2009).

The concentration of total protein, aspartate aminotransferase (AST, EC 2.6.1.1), alanine aminotransferase (ALT, EC 2.6.1.2), lactate dehydrogenase (LDH, EC 1.1.1.27), $\gamma$-glutamyltransferase (GTP, EC 2.3.2.2), and alkaline phosphatase (ALP, EC 3.1.3.1) activity was determined with standard laboratory test kits (Filisit-diagnostics and Reagent, Ukraine, Dnipro) according to (Burtis et al., 2012; Young, 2014), using the manufacturer's protocol. The activity of catalase (CT, EC 1.11.1.6) was determined by the ability of hydrogen peroxide to form a stable coloured complex with molybdenum salts (Koroliuk et al., 1988) and was expressed in $\mu \mathrm{cat} / \mathrm{mg}$ protein in all the examined fractions. The activity of superoxide dismutase (SOD, EC 1.15.1.1) was evaluated as the ability of the enzyme to inhibit quercetin oxidation (Kostjuk et al., 1990) and was expressed in conventional units (c.u./mg protein). The enzyme activity that was able to induce quercetin inhibition by $50 \%$ per $1 \mathrm{mg}$ tissue protein was taken as a unit. The concentration of TBA-active products was determined by the contents of the coloured complex formed by the reaction of malonic dialdehyde (MDA) in an acid medium with two molecules of thiobarbituric acid (TBA) (Andreeva et al., 1988). The amount of MDA was expressed in $\mu$ moles of TBA-active products per mg protein of the studied fraction. Carbonylated proteins were analyzed using the number of 2,4-dinitrophenylhydrazone derivatives that were formed in the reactions of oxidative amino acid residues with 2,4-dinitrophenylhydrazine and expressed in pmol derivatives of the carbonylation protein per mg protein (Lushchak, 2011). The concentration of pyruvate and lactate was determined calorimetrically. Pyruvic acid with 2,4-dinitrophenylhydrazine in alkaline medium forms 2,4-dinitrophenylhydrazones of pyruvic acid of brown-red colour, the intensity of which is proportional to the concentration of pyruvic acid. Lactic acid is converted into aldehyde acetate by heating with concentrated sulfuric acid, which, in the case of interaction with hydroquinone, forms a brownish-red compound (Melnichuk, 2014).

Results were statistically analyzed using the one-factor dispersion analysis ANOVA. For all statistical calculations, the significance was considered as the value of $\mathrm{P}<0.05$. Correlation was calculated with Pearson's coefficient test.

\section{Results}

Oxidizing processes prevailing under stress conditions cause changes in the biochemical processes of the whole organism, which have an instantaneous reflection on the homeostasis of blood. The most important parameters of blood, characterizing its homeostasis, are the level of hemoglobin and erythrocytes, whose indicator, in turn, is the value of hematocrit (Zakari et al., 2014; Salyha, 2013). These indices are mandatory diagnostic parameters that are differentially informative for the analysis of the state of the organism under normal conditions and the influence of various chemical and physical stress factors (Frigerio et al., 2017).

As a result of the combined effect of water-immobilization and emotional stress, hemoglobin content in the rats' blood dropped by $33 \%$ compared with the control group of animals (Table 1). The adaptation period, without the use of pharmacotherapy, was accompanied by the restoration of hemoglobin concentration 14 days after water-immobilization and emotional stress. The use of $\alpha$-ketoglutarate in drinking water for 14 days after stress caused an increase in hemoglobin by $62 \%$ compared to the group of stressed animals. It should also be noted that the hemoglobin concentration in these conditions was higher by $19 \%$ relative to the group of animals in adaptation and even exceeded the control group by $10 \%$ but corresponded to a range of normal values for rats (Morton et al., 1993; Evans, 1994). Changes in the hematocrit and the number of erythrocytes had a similar tendency. At the same time, under the conditions of water-immobilization and emotional stress, the adaptation period, and the use of $\alpha$-ketoglutarate, no probable changes in the parameters of red blood were observed: the average volume of erythrocytes, the average mass of hemoglobin in the erythrocyte, the average concentration of hemoglobin in the erythrocyte, and the colour index when compared with the control group of rats. Another trend was observed for the leukocyte formula. Thus, under water-immobilization and emotional stress, an increase in the number of leukocytes was recorded by $49 \%$, band cells - by $66 \%$, and segmented granular leukocytes - by $12 \%$, and lymphocyte and monocyte counts decreased by $13 \%$ and $14 \%$, respectively, compared to the control group. During the adaptation period, the number of band and segmented granular lymphocytes, and monocytes was determined to be at the level of the group of animals exposed to water-immobilization and emotional stress. At the same time, the number of leukocytes increased by $21 \%$ compared with the group of stressed animals. Under the conditions of $\alpha$-ketoglutarate, the number of band and segmented granular cells and lymphocytes were determined to be at the control group level, although the total number of leukocytes was elevated in comparison with the control group and with the group of animals exposed to water-immobilization and emotional stress. It is worth noting that the changes in these indicators fluctuated within the limits of physiological reference values (Morton et al., 1993; Evans, 1994). Basophils are not detected in the blood of experimental animals.

The liver plays a key role in the synthesis of blood proteins, in particular, hemoglobin, and the detoxification of their end metabolites. The determination of the biochemical status of the liver under stress factors is a current topical issue. According to the results of our experimental studies, the conditions of water-immobilization stress, in combination with emotional stress, for three days increased the activity of the main markers of the liver tissue: aspartate aminotransferase by $46 \%$, alanine aminotransferase by $53 \%$ (Fig. 1), $\gamma$-glutamyltranspeptidase by $38 \%$, and alkaline phosphatase by $17 \%$, while the activity of lactate dehydrogenase decreased by $35 \%$ (Fig. 2) compared with group 1 of animals.

During the 14-day adaptation period in the liver of the rats, alanine aminotransferase decreased by $18 \%$ and aspartate aminotransferase by $20 \%$ compared to stressed animals. Under the conditions of $\alpha$-ketoglutarate, the activity of aspartate aminotransferase was determined to be at the level of the values of the adaptation period. At the same time, alanine 
aminotransferase activity increased by $28 \%$ compared to the adaptation period and was higher by $60 \%$ compared with the control group. This increase is due to the specificity of the localization of alanine aminotransferase (preferably in the cytosol) and the use of additional $\alpha$-ketoglutarate as a substrate, resulting in an acceleration of the reaction of the formation of pyruvate. At the same time, pyruvate is involved in metabolic pathways: gluconeogenesis and cell respiration, as evidenced by data for reducing pyruvate concentration and stabilizing the activity of total lactate dehydrogenase in this experimental group of animals (Fig. 2). This finding is supported by the fact that the concentration of lactate was reduced by $39 \%$ compared with the adaptation period and by $62 \%$ compared with the group of animals exposed to stress (Fig. 3).

Table 1

Haematological and morphological parameters of the blood of rats $(x \pm S D, n=6)$

\begin{tabular}{|c|c|c|c|c|}
\hline Indicator & Control & WIS & Adaptation & $\alpha$-Ketoglutarate \\
\hline \multicolumn{5}{|l|}{ Hematologic indices } \\
\hline Hemoglobin, g/l & $136.0 \pm 5.34$ & $91.8 \pm 4.48^{*}$ & $125.5 \pm 10.74^{* *}$ & $150.7 \pm 8.23^{* . * * \#}$ \\
\hline Hematocrit, $\%$ & $33.3 \pm 1.20$ & $23.7 \pm 1.66^{*}$ & $31.5 \pm 2.77^{* *}$ & $36.1 \pm 2.38^{* * * . \#}$ \\
\hline \multicolumn{5}{|l|}{ Erythrocyte formula } \\
\hline Erythrocytes, $10^{12} / 1$ & $5.7 \pm 0.21$ & $4.0 \pm 0.33^{*}$ & $5.3 \pm 0.44^{* *}$ & $6.3 \pm 0.42^{* * * * \#}$ \\
\hline MCV (average volume of erythrocytes), $\mathrm{fl}\left(10^{-15} / \mathrm{l}\right)$ & $57.8 \pm 0.22$ & $58.9 \pm 1.69$ & $59.1 \pm 0.68$ & $57.7 \pm 0.26$ \\
\hline $\mathrm{MCH}$ (mean corpuscular haemoglobin) pg $\left(10^{-12} \mathrm{~g}\right)$ & $17.2 \pm 0.17$ & $16.7 \pm 0.46$ & $17.2 \pm 0.26$ & $17.4 \pm 0.39$ \\
\hline MCHC (mean corpuscular hemoglobin concentration), $\%$ & $29.7 \pm 0.24$ & $28.4 \pm 1.11$ & $29.1 \pm 0.19$ & $30.2 \pm 0.66$ \\
\hline Colour indicator, unit & $0.93 \pm 0.011$ & $0.91 \pm 0.032$ & $0.93 \pm 0.024$ & $0.95 \pm 0.021$ \\
\hline \multicolumn{5}{|l|}{ Leukocyte formula } \\
\hline Leukocytes, $10^{9} / 1$ & $6.5 \pm 1.05$ & $9.7 \pm 0.82^{*}$ & $11.7 \pm 1.43^{* . * *}$ & $11.2 \pm 1.87^{* * *}$ \\
\hline Basophils, \% & 0 & 0 & 0 & 0 \\
\hline Band cells, \% & $2.2 \pm 0.48$ & $3.6 \pm 0.4^{*}$ & $3.5 \pm 0.67^{*}$ & $2.7 \pm 0.42^{* * \# \#}$ \\
\hline Segmented granular cells nucleus, $\%$ & $35.7 \pm 2.47$ & $40.2 \pm 1.56^{*}$ & $39.7 \pm 1.08^{*}$ & $38.3 \pm 3.75^{* *}$ \\
\hline Lymphocytes, \% & $59.2 \pm 2.33$ & $51.6 \pm 1.29^{*}$ & $53.8 \pm 1.11^{*}$ & $58.8 \pm 3.14^{* * \#}$ \\
\hline Monocytes, \% & $2.3 \pm 0.21$ & $2.0 \pm 0.32^{*}$ & $2.0 \pm 0.26^{*}$ & $2.0 \pm 0.26^{*}$ \\
\hline
\end{tabular}

Note: control - group 1, WIS - group 2, adaptation - group 3, $\alpha$-ketoglutarate - group $4 ; *-\mathrm{P}<0.05$ differences are probably relative to group $1,{ }^{* *}-\mathrm{P}<0.05$ the differences are likely to be in relation to group 2 , $\#-\mathrm{P}<0.05$ the differences are likely to be in relation to group 3 .

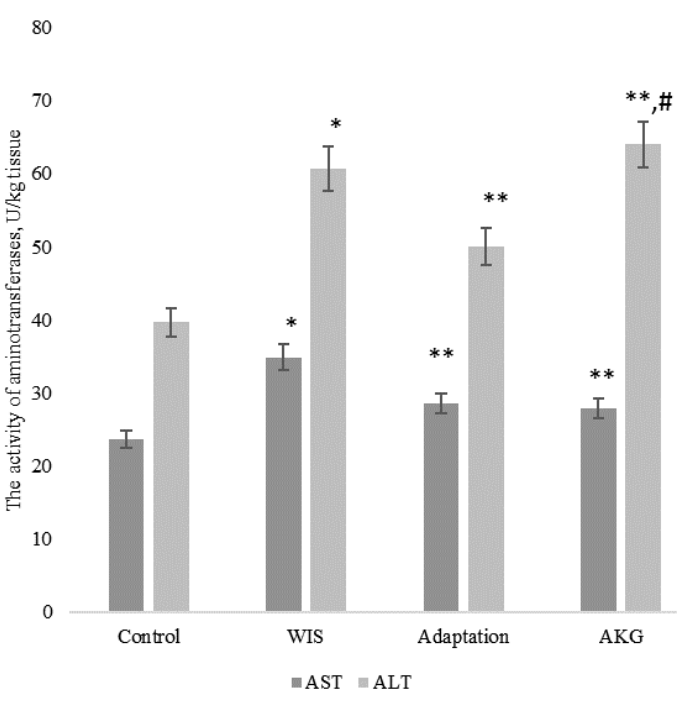

Fig. 1. The activity of aminotransferases:

aspartate aminotransferase (AST), alanine aminotransferase (ALT): $\mathrm{x} \pm \mathrm{SD}, \mathrm{n}=6$; see Table 1

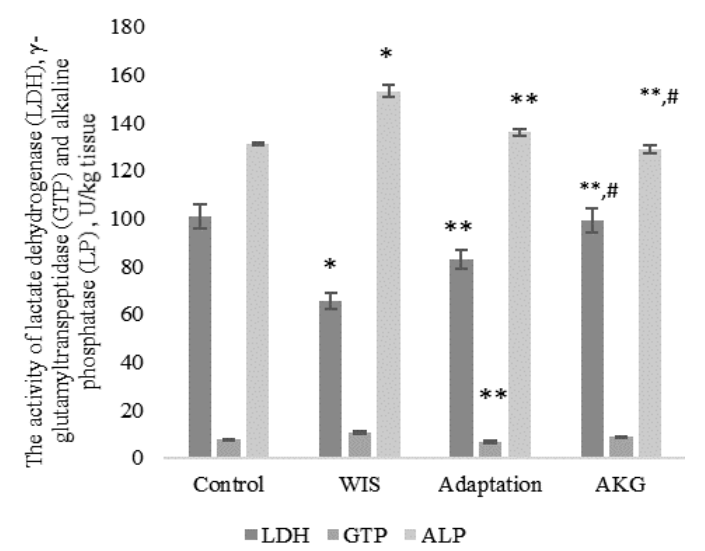

Fig. 2. The activity of lactate dehydrogenase (LDH), $\gamma$-glutamyltranspeptidase (GTP), and alkaline phosphatase (ALP): $\mathrm{x} \pm \mathrm{SD}, \mathrm{n}=6$; see Table 1
Under the conditions of the physiological adaptation of animals and the use of $\alpha$-ketoglutarate 14 days after stress, the activity of enzymes, defined as markers of the hepatobiliary system of the liver, $\gamma$-glutamyltranspeptidase and alkaline phosphatase, decreased to the level of values of the control group of animals (Fig. 2).

The increase in the liver concentration of lactate by $118 \%$ and pyruvate by $67 \%$ characterizes not only changes in the concentration of substrates, but also the shift of redox status towards oxidative processes under water-immobilization and emotional stress (Fig. 3). Under adaptive conditions, the pressure in the liver is gradually reduced (lactate $23 \%$ and pyruvate $43 \%$ compared to stressed animals). With the administration of $\alpha$-ketoglutarate in drinking water, the concentration of lactate and pyruvate in the liver of rats was very similar to the control values.

The combined effect of water-immobilization and emotional stress caused a shift in the redox status of the liver towards the strengthening of oxidative reactions, which was accompanied by an increase in concentrations not only of lactate and pyruvate (Fig. 3), but also of wellknown oxidizing stress markers - TBA-active products (by 72\%) and carbonylated proteins that have undergone oxidative modification (by 20\%) (Fig. 4).

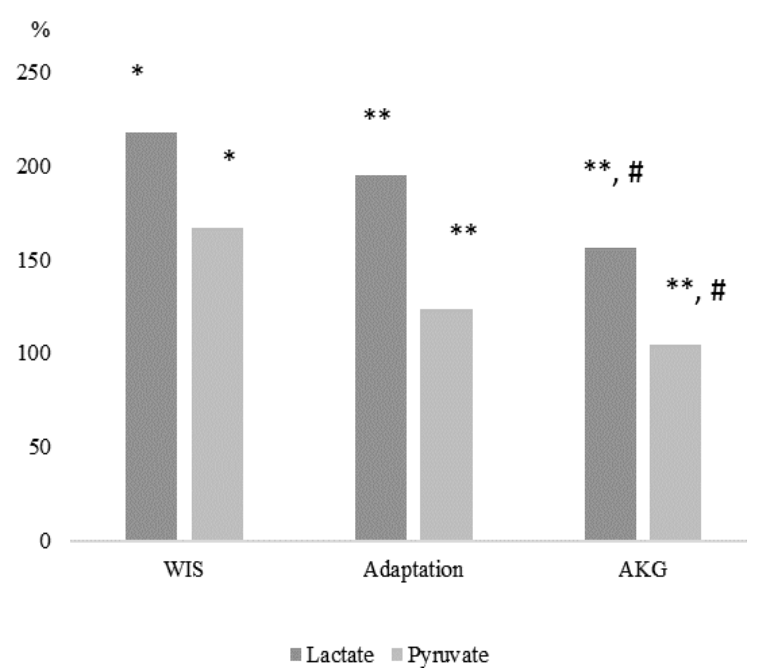

Fig. 3. The concentration of lactate and pyruvate ( $\%$ of control group): $\mathrm{x} \pm \mathrm{SD}, \mathrm{n}=6$; see Table 1 
3

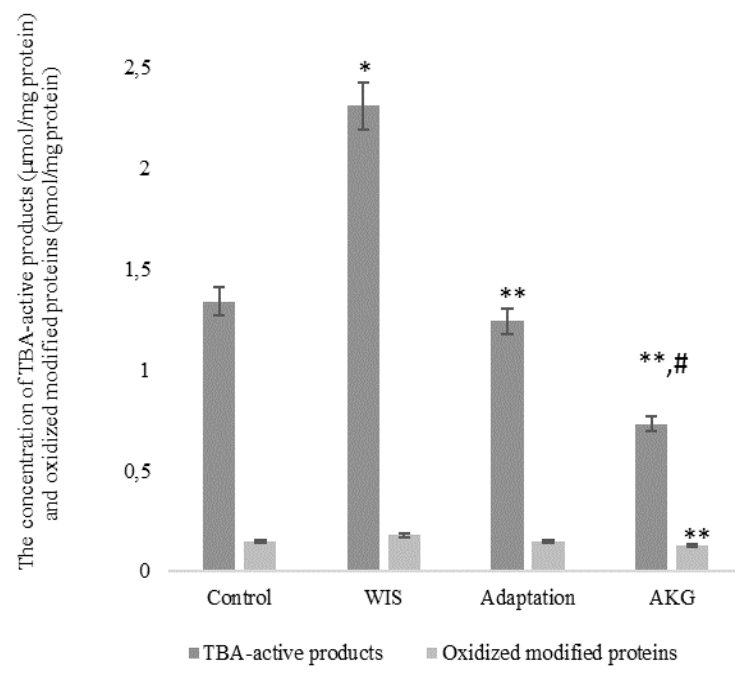

Fig. 4. The concentration of TBA-active products and oxidized modified proteins: $\mathrm{x} \pm \mathrm{SD}, \mathrm{n}=6$; see Table 1

It was been shown in this experiment, that in the liver, up to $20 \%$ protein modification occurs, while the concentration of TBA-active products, as a lipid oxidation marker, was increased by $72 \%$. Under the adaptation condition and the use of $\alpha$-ketoglutarate, decreases in the concentrations of TBA-active products by $68 \%$ and modified oxidized proteins by $14 \%$ were observed compared with stressed animals without any pharmaco-correction (Fig. 4).

Under the conditions of induction of oxidative stress under waterimmobilization and emotional stress, the increase in superoxide dismutase activity by $42 \%$ and inhibition of the activity of catalase by $50 \%$ were also observed (Fig. 5). After the physiological adaptation period and after stress in the rat liver, catalase activity increased by $25 \%$ relative to stressed animals, and the activity of superoxide dismutase decreased almost to the level of the control group. The use of $\alpha$-ketoglutarate for 14 days after stress stimulated the activity of enzymes in the direction of stabilization.

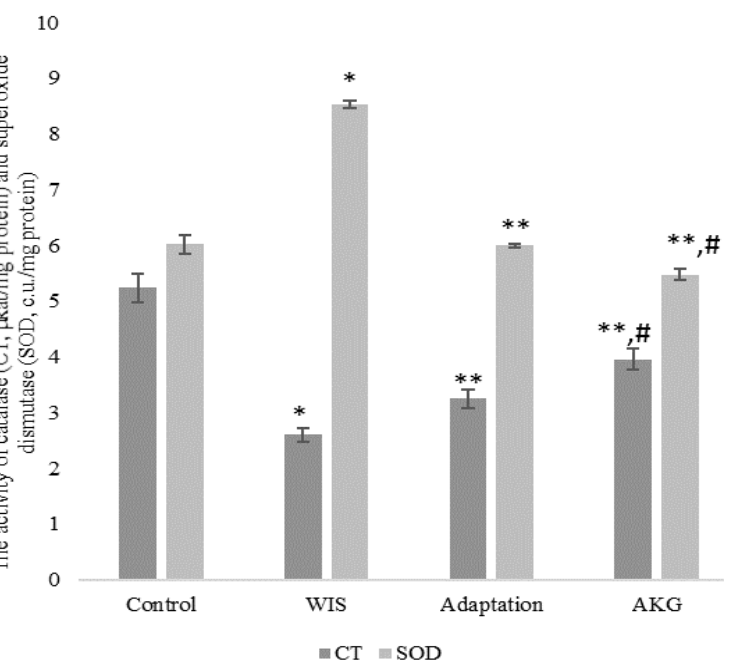

Fig. 5. The activity of catalase $(\mathrm{CT})$ and superoxide dismutase (SOD): $\mathrm{x} \pm \mathrm{SD}, \mathrm{n}=6$; see Table 1

\section{Discussion}

The main biochemical mechanism of changes in metabolic processes under stress is the first release of catecholamines, namely adrenaline in the blood, and their effect on organs and tissues. The increase in adrenaline leads to a complex of biochemical changes in both the blood and the liver. Strengthening of the vasoconstriction of vessels by the action of adrenaline leads to a decrease in the aeration of organs, which provokes their hypoxic state.

The concentration of hemoglobin in the blood is directly dependent on the number of red blood cells (Khariv, 2013; Grabovskyi, 2014). In our experiments, we found decreased concentration of hemoglobin, erythrocyte count, and hematocrit in the blood of rats under water-immobilization and emotional stress (Table 1), confirming the extreme sensitivity of hematological parameters to the action of stress factors and indicating the negative effects associated with the aggravation of hypoxia in the liver, which causes the slowdown of metabolic processes in its cells. Similar changes in blood are used as markers of the level of the hematopoietic function of the bone marrow. To confirm the state of the hematopoietic function of the bone marrow, the values of red blood indices are examined: the average volume of one erythrocyte (MCV), of which increasing the value (macrocytosis) is an indicator of mild polycythemia; the average mass of haemoglobin in erythrocytes $(\mathrm{MCH})$ is high in hemolytic and myelin toxic anaemia; the average concentration of haemoglobin (MCHC) increases after hyperchromic anaemia and decreases in case of iron deficiency anaemia (Khariv, 2013; Grabovskyi, 2014; Khariv et al., 2016). Hematocrit reflects the number of all formed blood elements, mainly red blood cells. The results we obtained indicate the presence of erythrocyte hemolysis (reduction of erythrocytes and hemoglobin concentration) under the conditions of water-immobilization and emotional stress. In this case, the stability of the indicators of red blood shows the preservation of the hematopoietic function of the bone marrow. The reference values of the leukocyte formula are: leukocytes - 2.1$19.610 \% /$; band cells $-0-5 \%$; segmented granular cells $-12-31 \%$; lymphocytes - 55-77\%; monocytes - 1-5\% (Morton et al., 1993; Evans, 1994; Kocharniy et al., 2017). Changes in the indicators of the leukocyte formula of all examined groups (Table 1) occurred within these reference values, demonstrating the regulation of adaptation processes in the blood of experimental animals. However, an increase in the number of leukocytes in the blood of rats during the adaptation period after stress suggests a distant response of the organism to the action of stress factors.

According to the results of the experiments, over combined waterimmobilization and emotional stress for three days, the activity of the main markers of the state of the hepatic tissue, aspartate aminotransferase and alanine aminotransferase (Fig. 1) and $\gamma$-glutamyltranspeptidase and alkaline phosphatase (Fig. 2) increased, while the activity of lactate dehydrogenase (Fig. 2) decreased compared with the control group of animals. The obtained data show the reactivity of the hepatic tissue in response to the action of stress factors, which is manifested as a violation of the functioning of liver cells in both the central part and the hepatobiliary system. It should be noted that the increase in the activity of aspartate aminotransferase in the liver indicates an increase in the permeability of the mitochondrial membrane under stress since the highest activity of this enzyme is detected in mitochondria.

The increase in the concentration of lactate and pyruvate in the liver characterizes not only changes in the concentration of substrates for enzymes, but also the displacement of the redox status in the direction of oxidative processes under water-immobilization and emotional stress (Fig. 3). Under conditions of immobilization stress, there is a change in the balance between prooxidant and antioxidant systems in the direction of the growth of the prooxidant system and inhibition of the antioxidant system (Svan, 2015). The combined effect of water-immobilization and emotional stress caused a shift of the redox status of the liver towards the increase of oxidative reactions, which was accompanied by an increase in concentrations not only of lactate and pyruvate (Fig. 3), but also of well-known oxidizing stress markers - TBA-active products and carbonylated proteins, which were subjected to oxidative modifycation (Fig. 4), as well as increased activity of superoxide dismutase and inhibition of catalase activity (Fig. 5).

The significant increase in the concentration of TBA-active products under conditions of water-immobilization and emotional stress indicates an increase in the lipid peroxidation in liver cell membranes, which are mainly represented by phospholipids. Most likely, the toxic metabolites produced under such conditions in the body and which are subject to detoxification in the liver indirectly trigger oxidation reactions. In addition, the formation of oxidative stress causes an oxidative 
modification of proteins. The determination of the concentration of such damaged proteins is an early indicator of damage to organs and tissues and requires constant monitoring (Miller et al., 2004; Pasko, 2016). Thus, in this experiment, we showed that in the case of water-immobilization and emotional stress, $20 \%$ of proteins are modified while the concentration of TBA-active products is increased by $72 \%$, which indicates greater lipid vulnerability to oxidation under stress conditions than proteins.

During the physiological adaptation period of 14 days after stress, there was a decrease in the activity of alanine aminotransferase and aspartate aminotransferase in the direction of control values compared to stressed animals, but not until complete recovery. Also, in the context of adaptation, the activity of enzymes, defined as markers of the state of the hepatobiliary system, $\gamma$-glutamyltranspeptidase and alkaline phosphatase, decreased to the level of the activity values of these enzymes in the control group of animals (Fig. 2). The activity of enzymes, markers of the state of the antioxidant system, under the same conditions reacted as follows: catalase increased in the direction of control values, and superoxide dismutase decreased to the level of the control group.

Currently, research is being actively conducted on natural substances that can act as hepato- and hematoprotectors under the influence of negative factors, especially stress factors which have become an almost constant component of modern life. $\alpha$-Ketoglutarate is an important intermediate of the Krebs cycle, which is involved in providing cells with energy, as well as in the metabolism of amino acids and proteins. It has been proven experimentally that the addition of $\alpha$-ketoglutarate to animal diets can improve protein metabolism and stimulate energy metabolism in the body (Harrison \& Pierzynowski, 2008). In medicine and dietetics, $\alpha$-ketoglutarate is used to stimulate metabolic processes and restore muscle damage (Yao, 2012) and reverse brain ischemia (Kovalenko et al., 2011). Given the studied properties of exogenous $\alpha$-ketoglutarate, the issue of possible mechanisms of action of $\alpha$-ketoglutarate and its participation in the formation of redox status remains unresolved.

In our studies, we showed that the administration of $0.8 \mathrm{~g} / \mathrm{kg}$ body weight of $\alpha$-ketoglutarate in drinking water for 14 days after stress, led to a gradual decrease in the oxidative pressure in the liver, as indicated by a decrease in the concentration of lactate, pyruvate, TBA-active products, and oxidized modified proteins compared with stressed animals without the use of any pharmaco-correction (Fig. 4). Also shown are the increased activity of catalase and stabilization of superoxide dismutase activity in the rat liver to the level of control values. Previous research (Desagher et al., 1997; Kovalenko et al., 2011) has proven the ability of ketoacids to inhibit oxidative stress in particular, due to their participation in the glutamate-glutamine cycle, which reduces glutamate intoxication. Under hypoxic conditions, aeration of cells, which inhibits aerobic processes of the Krebs cycle in the liver, is reduced. The result of such events is a decrease in the concentration of endogenous $\alpha$-ketoglutarate. The addition to drinking water of exogenous $\alpha$-ketoglutarate after stress provides the ability to deliver the substrate as a reaction to neutralize oxidative products, and to prevent the leakage of $\alpha$-ketoglutarate from the Krebs cycle and the production of reduced equivalents for the respiratory chain of mitochondria. In addition, $\alpha$-ketoglutarate promotes the more effective inclusion of pyruvate to gluconeogenesis (the predominant process of carbohydrate metabolism in the liver) and the gradual conversion of lactate to pyruvate in lactate dehydrogenase activity, the activity detected at the control group level under the conditions of using $\alpha$-ketoglutarate after stress. Our results indicate the redox status restoration and improvement of the physiological state of the liver and, accordingly, the hematological parameters in rats receiving $\alpha$-ketoglutarate for 14 days after stress. The revealed general positive trend suggests the stimulation of adaptation processes and the overall functioning of the antioxidant system of the liver of rats in the use of $\alpha$-ketoglutarate against the background of combined effects of water-immobilization and emotional stress.

In the background of the overall positive effect of $\alpha$-ketoglutarate after stress on marker enzymes of the liver hepatobiliary system, we noted the stabilization of $\gamma$-glutamyltranspeptidase and alkaline phosphatase activity (Fig. 2). Under the conditions of $\alpha$-ketoglutarate, the activity of aspartate aminotransferase was determined to be at the level of the values of the adaptation period. $\alpha$-Ketoglutarate has a multi-vector effect due to its direct involvement in transamination reactions, which are basic in the exchange of amino acids for the synthesis of de novo proteins, providing intermediate parts of the process of detoxification of ammonia with the participation of glutamate dehydrogenase and aspartate aminotransferase. At the same time, the activity of alanine aminotransferase after the use of $\alpha$-ketoglutarate increased in comparison with the adaptation period and was higher than the control values. Such changes are likely to be due to the specificity of the localization of alanine aminotransferase (preferably in the cytosol) and the use of additional $\alpha$-ketoglutarate as a substrate, which results in the acceleration of the reaction of the formation of pyruvate. This leads to a more effective involvement of pyruvate in the metabolic pathways: gluconeogenesis and respiration of the cell, as evidenced by data on reduced pyruvate concentration, stabilization of total lactate dehydrogenase activity, and decreased lactate concentration in this experimental group of animals.

\section{Conclusion}

The overall positive influence of $\alpha$-ketoglutarate on the liver and blood of rats exposed to the combined effects of water-immobilization and emotional stress was determined. The administration of $0.8 \mathrm{~g} / \mathrm{kg}$ of body weight of $\alpha$-ketoglutarate for 14 days after stress reduces the severity of hepatic tissue damage and/or prevents complications in the liver after exposure to stress factors, normalizes liver function, and improves its redox status significantly. The biochemical mechanism of the positive effect of $\alpha$-ketoglutarate on the functional activity of the liver of animals is manifested in the increament of the antioxidant protection of cells via increasing the adaptive processes by increasing the activity of catalase and stabilizing the synthetic function of the liver, which improves hematological and morphological parameters of the blood.

\section{References}

Andrae, U., Singh, J., \& Ziegler-Skylakakis, K. (1985). Pyruvate and related alphaketoacids protect mammalian cells in culture against hydrogen peroxideinduced cytotoxicity. Toxicology Letters, 28, 93-98.

Andreeva, L. Y., Kozhemjakyn, L. A., \& Kyshkun, A. A. (1988). Modification of the method for the determination of lipid peroxides in the test with thiobarbituric acid. Laboratornoe Delo, 2, 41-43.

Banerjee, K., Munshi, S., Xu, H., Frank, D. E., Chen, H-L., Chu, C. T., Yang, J., Cho, S., Kagan, V. E., Denton, T. T., Tyurina, Y. Y., Jiang, J. F., \& Gibson, G. E. (2016). Mild mitochondrial metabolic deficits by $\alpha$-ketoglutarate dehydrogenase inhibition cause prominent changes in intracellular autophagic signaling: Potential role in the pathobiology of Alzheimer's disease. Neurochemistry International, 96, 32-45.

Baulies, A., Montero, J., Matías, N., Insausti, N., Terrones, O., Basañez, G., Vallejo, C., Conde de La Rosa, L., Martinez, L., Robles, D., Morales, A., Abian, J., Carrascal, M., Machida, K., Kumar, D. B. U., Tsukamoto, H., Kaplowitz, N., Garcia-Ruiz, C., \& Fernández-Checa, J. C. (2018). The 2-oxoglutarate carrier promotes liver cancer by sustaining mitochondrial GSH despite cholesterol loading. Redox Biology, 14, 164-177.

Burtis, C., Ashvud, E., \& Bruns, D. (2012). Text book of clinical chemistry and molecular diagnostics. WB Saunders, Philadelphia.

Dakshayani, K. B., Subramanian, P., Manivasagam, T., \& Essa, M. M. (2006). Metabolic normalization of alpha-ketoglutarate against $\mathrm{N}$-nitrosodiethylamineinduced hepatocarcinogenesis in rats. Fundamental and Clinical Pharmacology, 20, 477-480.

Desagher, S., Glowinski, J., \& Prémont, J. (1997). Pyruvate protects neurons against hydrogen peroxide-induced toxicity. Journal of Neuroscience, 17, 9060-9067.

Dyomshina, O. O., Ushakova, G. O., \& Stepchenko, L. M. (2017). The effect of biologically active feed additives of humilid substances on the antioxidant system in liver mitochondria of gerbils. Regulatory Mechanisms in Biosystems, 8(2), 185-190.

Evans, G. O. (1994). Removal of blood from laboratory mammals and birds. Laboratory Animals, 28(2), 178-179.

Frigerio, D., Ludwig, S. C., Hemetsberger, J., Kotrschal, K., \& Wascher, C. A. F. (2017). Social and environmental factors modulate leucocyte profiles in freeliving Greylag geese (Anser anser). PeerJ, 5, e2792.

Grabovskyi, S. S. (2014). Effect of natural immunomodulators influence on cellular immunity indices and cortisol level in rat's blood at pre-slaughter stress. Studia Biologica, 8(1), 93-102.

Harrison, A. P., \& Pierzynowski, S. G. (2008). Biological effects of 2-oxoglutarate with particular emphasis on the regulation of protein, mineral and lipid ab- 
sorption/metabolism, muscle performance, kidney function, bone formation and cancerogenesis, all viewed from a healthy ageing perspective state of the hart-review article. Journal of Physiology and Pharmacology, 59(1), 91-106.

Hlinic, S. V., Romanovsky, I. V., Rineyskaya, O. N., Kartun, L. V., \& Khodosovskaya, E. V. (2007). Hormonal status and the state of the lipid peroxidation system in the brain tissue of rats under cold stress on the background of experimental hypothyroidism. Proceedings of the National Academy of Sciences of Belarus, Series of Medical Sciences, 2, 55-59.

Khariv, I. I. (2013). Vplyv "Amprolinsylu" ta brovitakoktsydu na pokaznyky klitynnoho i humoral'noho imunitetu indykiv za eymeriozo-histomonoznoyi invaziyi [Influence of amprolissil and broth tacticide on indicators of cell and humoral immunity of turkey cocks under the emeritus-histomonous invasion]. Biolohiya Tvaryn, 15(4), 159-165.

Khariv, M., Gutyj, B., Butsyak, V., \& Khariv, I. (2016). Hematolohichni pokaznyky orhanizmiv shchuriv v umovakh okyslyuval'noho stresu ta diyi liposomal'noho preparatu [Hematological indices of rat organisms under conditions of oxidative stress and liposomal preparation action]. Biological Bulletin of Bogdan Chmelnitskiy Melitopol State Pedagogical University, 6(1), 276-289.

Khnychenko, L. K., \& Sapronov, N. S. (2003). Stress and its role in the development of pathological processes. Reviews on Clinical Pharmacology and Drug Therapy, 2(3), 2-15.

Kocharniy, V. V., Rutgaizer, V. G., Abdul-Ogly, L. V., Magro, V. I., \& Kumchenko, V. V. (2017). Zminy pokaznykiv krovi u shchuriv pislya vplyvu elektromahnitnoho vyprominyuvannya [Change of the blood indexes rats following the influence of the electromagnetic radiation]. Journal of Clinical and Experimental Pathology, 16(2), 28-32.

Koroliuk, M. A., Ivanova, L. I., Mayorova, I. G., \& Tokarev, V. E. (1988). A method of determining catalase activity. Laboratornoe Delo, 1, 16-19.

Kostjuk, V. A., Potapovych, A. Y., \& Kovaleva, Z. V. (1990). A simple and sensitive method for determining the activity of superoxidedismutase, based on the oxidation reaction of quercetin. Questions of Medical Chemistry, 36(2), 88-91.

Kovalenko, T. N., Ushakova, G. A., Osadchenko, I., Skibo, G. G., \& Pierzynowski, S. G. (2011). The neuroprotective effect of 2-oxoglutarate in the experimenttal ischemia of hippocampus. Journal of Physiology and Pharmacology, 62(2), 239-246.

Krebs, H. A., \& Johnson, W. A. (1980). The role of citric acid in intermediate metabolism in animal tissues. FEBS Letters, 117(Suppl.), K1-10.

Long, L. H., \& Halliwell, B. (2011). Artefacts in cell culture: $\alpha$-ketoglutarate can scavenge hydrogen peroxide generated by ascorbate and epigallocatechin gallate in cell culture. Biochemical and Biophysical Research Communications, 406(1), 20-24.

Lushchak, V. I. (2015). Free radicals, reactive oxygen species, oxidative stresses and their classifications. The Ukrainian Biochemical Journal, 87(6), 11-18.

Lushchak, V. I., Semchyshyn, H. M., \& Lushchak, O. V. (2011). The classic methods to measure oxidative damage: Lipid peroxides, thiobarbituric acid reactive substances, and protein carbonyls. Oxidative Stress in Aquatic Ecosystems, 32, 420-431.

Mehra, L., Hasija, Y., \& Mittal, G. (2016). Therapeutic potential of alpha-ketoglutarate against acetaminophen-induced hepatotoxicity in rats. Journal of Pharmacy and Bioallied Sciences, 8(4), 296-299.

Mikhaylenko, E. A., Dyomshina, O. O., Ushakova, G. O., \& Stepchenko, L. M. (2016). Efektivnist' antyoksydantnoyi systemy pechinky brojleriv krosu Kobb500 pry vypojuvanni pryrodnymy biologichno aktyvnymy dobavkamy na osnovi guminovyh rechovyn [The effectiveness of the antioxidant system of the liver of broilers of the Cobb-500 cross-breeder when dispensing with natural biologically active additives on the basis of humic substances]. Visnyk Derzhavnogo Agrarno-Ekonomichnogo University, 42(4), 120-125.

Miller, E., Walczak, A., Saluk, J., Ponczek, M. B., \& Majsterek I. (2012). Oxidative modification of patient's plasma proteins and its role in pathogenesis of multiple sclerosis. Clinical Biochemistry, 45(1-2), 26-30.

Morton, D. B., Abbot, D., Barclay, R., Close, B. C., Ewbank, R., Gask, D., Heath M., Mattic, S., Poole, T., Seamer, J., Southee, J., Thompson, A., Trussell, B. West, G., \& Jennings, M. (1993). Removal of blood from laboratory mammals and birds: First report of the BVA/FRAME/RSPCA/UFAW Joint Working Group on Refinement. Laboratory Animals, 27(1), 1-22.

Pasko, A. Y. (2016). Doslidzhennya rivnya produktiv okysnoyi modyfikatsiyi bilkiv ta antyoksydantnykh fermentiv u patsiyentiv $\mathrm{z}$ pislyaoperatsiynym hipoparatyreozom [Study of the level of products of oxidative modification of proteins and antioxidant enzymes in patients with postoperative hypoparathyroidism]. Bukovinian Medical Herald, 20(2),116-120.

Sahafi, E., Peeri, M., Hosseini, M. J., \& Azarbyjani, M. A. (2018). Cardiac oxidative stress following maternal separation stress was mitigated following adolescent voluntary exercise in adult male rat. Physiology and Behavior, 183, 39-45.

Salyha, N. O. (2013). Funktsionuvannya antyoksydantnoyi systemy shchuriv na diyu L-hlutamynovoyi kysloty ta tsysteyinu na tli eksperymental'noho stresu
Functioning of the antioxidant system of rats on the action of L-glutamic acid and cysteine against the background of experimental stress]. Zhurnal of V. N. Karazin Kharkiv National University, Series Biology, 1056, 21-25.

Sawa, K., Uematsu, T., Korenaga, Y., Hirasawa, R., Kikuchi, M., Murata, K., Zhang, J., Gai, X., Sakamoto, K., Koyama, T., \& Satoh, T. (2017). Krebs cycle intermediates protective against oxidative stress by modulating the level of reactive oxygen species in neuronal HT22 cells. Antioxidants, 6(1), 21

Semchyshyn, H. M., \& Lushchak, V. I. (2012). Interplay between oxidative and carbonyl stresses: Molecular mechanisms, biological effects and therapeutic strategies of protection. In: Lushchak, V. I., \& Semchyshyn, H. M. (Eds.). Oxidative stress - Molecular mechanisms and biological effects. Pp. 15-46.

Serova, D., Taran, O., \& Dyomshina, O. (2016). Biological activity of humic substances in the liver of Mongolian gerbils (Meriones unguiculatus). Visnyk of Dnipropetrovsk University, Biology, Ecology, 24(2), 410-415.

Shmarakov, I. O., Borschovetska, V. L., \& Marchenko, M. N. (2014). Features generation of reactive oxygen and nitrogen acute hepatotoxicity. Visnyk of Dnipropetrovsk University, Biology, Ecology, 22(1), 3-7.

Sokołowska, M., Oleszek, A., \& Włodek, L. (1999). Protective effect of alphaketo acids on the oxidative hemolysis. Polish Journal of Pharmacology, 51, 429-434.

Sookoian, S., \& Pirola, C. J. (2015). Liver enzymes, metabolomics and genomewide association studies: From systems biology to the personalized medicine. World Journal of Gastroenterology, 21(3), 711-725.

Sterling, S. A., Puskarich, M. A., \& Jones, A. E. (2015). The effect of liver disease on lactate normalization in severe sepsis and septic shock: A cohort study, Clinical and Experimental Emergency Medicine, 2(4), 197-202.

Svan, O. B. (2015). Vplyv hostroho stresu na funktsiyi donora zhovchi pechinky v umovakh kryokhirurhiyi shkiry v eksperymenti [Influence of acute stress on bile donor function of the liver under conditions of skin cryosurgery in the experiment]. Dosyahnennya Klinichnoyi ta Eksperymental'noyi Medytsyny, 2-3, 135-137.

Tkachenko, V., Kovalchuk, Y., Bondarenko, N., Bondarenko, O., Ushakova, G., $\&$ Shevtsova, A. (2018). The cardio- and neuroprotective effects of corvitin and 2-oxoglutarate in rats with pituitrin-isoproterenol-induced myocardial damage. Biochemistry Research International, 2018, ID 9302414

Usende, I. L., Olopade, J. O., Emikpe, B. O., Oyagbemi, A. A., \& Adedapo, A. A (2018). Oxidative stress changes observed in selected organs of African giant rats (Cricetomys gambianus) exposed to sodium metavanadate. International Journal of Veterinary Science and Medicine, 6(1), 80-89.

Ushakova, G., Fomenko, O., \& Pierzynowski, S. (2010). Non-invasive markers of hepatic encephalopathy under chronic hepatitis $\mathrm{C}$ and 2-oxoglutarate treatment. Annales Universitatis Mariae Curie-Sklodowska, 23(3), 203-206.

Velvizhi, S., Dakshayani, K. B., \& Subramanian, P. (2002). Effects of alpha-ketoglutarate on antioxidants and lipid peroxidation products in rats treated with ammonium acetate. Nutrition, 18, 747-750.

Vincent, J. L., Quintairos, E. S. A., Couto, L., \& Taccone, F. S. (2016). The value of blood lactate kinetics in critically ill patients: A systematic review, Critical Care, 20(1), 257

Volkova, S. V., \& Meleshkina, S. R. (2008). Stress of farm animals as a response to adverse environmental conditions. Modern Science-Intensive Technologies, 4, 55-56.

Warille, A. A., Altun, G., Elamin, A. A., Kaplan, A. A., Mohamed, H., Yurt, K. K \& El Elhaj, A. (2017). Skeptical approaches concerning the effect of exposure to electromagnetic fields on brain hormones and enzyme activities. Journal of Microscopy and Ultrastructure, 5, 177-184.

Weiner, H. (1996). Use of animal models in pepticulcer disease. Psychosomatic Medicine, 58(6), 524-545.

Wieckowski, M. R., Giorgi, C., Lebiedzinska, M., Duszynski, J., \& Pinton, P. (2009). Isolation of mitochondria-associated membranes and mitochondria from animal tissues and cells. Nature Protocols, 4(11), 1582-1590.

Wu, X., Zhang, L., Miao, Y., Yang, J., Wang, X., Wang, C. C., Feng, J., \& Wang, L. (2018). Homocysteine causes vascular endothelial dysfunction by disrupting endoplasmic reticulum redox homeostasis. Redox Biology, 26, 46-59.

Yao, K, Yin, Y, Li, X, Xi, P., Wang, J., Lei, J, Hou, Y, \& Wu, G. (2012). Alpha-ketoglutarate inhibits glutamine degradation and enhances protein synthesis in intestinal porcine epithelial cells. Amino Acids, 42(6), 2491-2500.

Young, D. S. (2014). Effects on clinical laboratory tests: Drugs, disease, herbs and natural products. American association for clinical chemistry, John Wiley \& Sons, Inc.

Zakari, F. O., Ayo, J. O., Rekwot, P. I., \& Kawu, M. U. (2014). Effect of age, sex, physical activity and meteorological factors on haematological parameters of donkeys (Equus asinus). Comparative Clinical Pathology, 25(6), 1265-1272.

Zdzisińska, B., Żurek, A., Kandefer-Szerszeń, M. (2016). Alpha-ketoglutarate as a molecule with pleiotropic activity: Well-known and novel possibilities of therapeutic use. Archivum Immunologiae et Therapiae Experimentalis, $65(1), 21-36$ 